\title{
Content validation of the nursing diagnosis Nausea*
}

\author{
VALIDAÇÃO DE CONTEÚDO DO DIAGNÓSTICO DE ENFERMAGEM NÁUSEA
}

VALIDACIÓN DE CONTENIDO DEL DIAGNÓSTICO DE ENFERMERÍA NÁUSEA

\author{
Daniele Alcalá Pompeo', Lídia Aparecida Rossi², Luciana Paiva
}

\begin{abstract}
This study aimed to evaluate the content validity of the nursing diagnosis of nausea in the immediate post-operative period, considering Fehring's model. Descriptive study with 52 nurses experts who responded an instrument containing identification and validation of nausea diagnosis data. Most experts considered the domain 12 (Comfort), Class 1 (Physical Comfort) and the statement (Nausea) adequate to the diagnosis. Modifications were suggested in the current definition of this nursing diagnosis. Four defining characteristics were considered primary (reported nausea, increased salivation, aversion to food and vomiting sensation) and eight secondary (increased swallowing, sour taste in the mouth, pallor, tachycardia, diaphoresis, sensation of hot and cold, changes in blood pressure and pupil dilation). The total score for the diagnosis of nausea was 0.79 . Reports of nausea, vomiting sensation, increased salivation and aversion to food are strong predictors of nursing diagnosis of nausea.
\end{abstract}

\section{RESUMO}

Este estudo teve como objetivo avaliar a validade de conteúdo do diagnóstico de enfermagem Náusea no período pós-operatório imediato, considerando-se o modelo de Fehring. Estudo descritivo com 52 expertos que responderam um instrumento que continha dados de identificação e de validação do diagnóstico Náusea. A maioria dos expertos considerou o domínio 12 (Conforto), a classe 1 (Conforto físico) e o enunciado (Náusea) adequados ao diagnóstico. Foram sugeridas modificações na definição atual do diagnóstico de enfermagem em estudo. Quatro características definidoras foram consideradas principais (relato de náusea, salivação aumentada, aversão à comida e sensação de vômito) e oito secundárias (deglutição aumentada, gosto amargo na boca, palidez, taquicardia, diaforese, sensação de calor e frio, alterações da pressão arterial e dilatação pupilar). O escore total do diagnóstico Náusea foi de 0,79 . O relato de náusea, sensação de vômito, salivação aumentada e aversão à comida são fortes indicativos do diagnóstico de enfermagem Náusea.

\section{DESCRITORES}

Diagnóstico de enfermagem Náusea

Cuidados pós-operatórios

Estudos de validação

\section{RESUMEN}

Este estudio tuvo como objetivo evaluar la validez de contenido del diagnóstico de enfermería de las náuseas en el postoperatorio inmediato, teniendo en cuenta el modelo de Fehring. Se trata de un estudio descriptivo con 52 expertos que respondieron un instrumento que contenía los datos de identificación y validación del diagnóstico de náuseas. La mayoría de los expertos consideran el dominio 12 (Confort), Clase 1 (Confort físico) y el estado (Náusea) adecuados para el diagnóstico. Fueron sugeridas modificaciones en la definición actual del diagnóstico de enfermería en estudio. Se consideraron cuatro características definitorias como principales (verbalización de náuseas, aumento de la salivación, aversión a la comida y sensación de vómito) y ocho secundarias (aumento de la deglución, sabor amargo en la boca, palidez, taquicardia, sudoración, sensación de calor y frío, cambios en la presión arterial y dilatación de la pupila). La puntuación total del diagnóstico de náusea fue de 0,79. El reporte de náuseas, sensación de vómito, aumento de la salivación y la aversión a los alimentos sólidos son fuertes indicadores del diagnóstico de enfermería de náusea.

\section{DESCRIPTORES}

Diagnóstico de enfermería

Náusea

Cuidados postoperatorios

Estudios de validación

Estudios de validación

\footnotetext{
*Extracted from thesis "Validação do diagnóstico de enfermagem náusea no período pós-operatório imediato", Inter-Unit Doctoral Program in Nursing of Ribeirao Preto School of Nursing, University of Sao Paulo, 2012. 1 Professor, PhD, Specialized Nursing Departament, Sao Jose do Rio Preto Faculty of Medicine, Sao Jose do Rio Preto, SP, Brazil. daniele.pompeo@famerp.br ${ }^{2}$ Full Professor, Ribeirao Preto School of Nursing, University of Sao Paulo, Ribeirao Preto, SP, Brazil. ${ }^{3} \mathrm{PhD}$ student, Ribeirao Preto School of Nursing, University of Sao Paulo, Ribeirao Preto, SP, Brazil.
}

$\begin{array}{rr}\text { Rev Esc Enferm USP } & \text { Received: } 06 / 26 / 2013 \\ \text { 2014; 48(1):48-56 } & \text { Approved: } 12 / 05 / 2013\end{array}$




\section{INTRODUCTION}

For a nursing diagnosis to be included in the NANDA-I taxonomy or to go through the review process, it needs to be based on research, such as concept analysis, content validity, and construct validity and related criteria, validation by consensus and studies about diagnostic accuracy ${ }^{(1)}$.

The validation of nursing diagnoses is recommended for all their components, i.e. title, definition, defining characteristics, related factors, and even for the taxonomic structure itself, as it has been done in other classifications $^{(2)}$. Most researches currently have focused only on validation of defining characteristics contained in a diagnosis of NANDA-I taxonomy ${ }^{(3-4)}$. The analysis of all components provides subsidies for understanding not only nursing diagnoses studied, but also the sphere of activity in which it is inserted.

Depending on the objectives of the researcher, one can validate nursing diagnoses considering three models of validation: Diagnostic Content Validation - DCV; Clinical Diagnostic Validation - CDV and Differential Diagnostic Validation - DDV ${ }^{(5)}$.

The Diagnostic Content Validation, object of this study, is based on opinions of nurses experts or judges about the degree to which each defining characteristic is indicative of a particular nursing diagnosis. The author recommends conducting a literature review prior to use of the method, in order to provide theoretical support for the understanding of the studied diagnosis and its components ${ }^{(5)}$.

Before the Nursing Diagnosis Content Validation, other researchers have emphasized the need to conduct an integrative review of the literature, aiming to summarize the research on a particular subject in a systematic manner, and follow standards of methodological rigor, which enable the reader to identify the characteristics of the analyzed studies and provide subsidies to the advancement of nursing ${ }^{(6)}$.

The nursing diagnosis of nausea, present in the NANDA-I taxonomy II ${ }^{(1)}$ is focused in the context of cancer patients, it does not express comprehensively the real needs of patients in the post-operative period. Moreover, in the specific literature of the post-operative period, we find numerous studies addressing factors related to nausea, which are not described in NANDA-I and are identified frequently in clinical practice. Therefore, it is recommended to conduct validation studies, aimed at reviewing the elements that constitute the diagnosis of Nausea, making it more accurate to guide, effectively, the establishment of outcomes and nursing interventions.

The aim of this study was to assess the content validity of nursing diagnosis of Nausea in the immediate postoperative period, considering Fehring's model $\mathrm{l}^{(5)}$.

\section{METHOD}

Non-experimental, descriptive study whose population was composed of experts on the studied nursing diagnosis. The content validation does not require sample size calculation, however, the model used in this study recommends the need for 50-100 nurses ${ }^{(5)}$.

Some criteria have been described so that a nurse may be considered an expert on nursing diagnosis. Each criterion described presents a score, and to be considered an expert, the person needs to obtain a minimum of five points (criteria/points: Master Degree in Nursing: 4; Master Degree in nursing with dissertation content directed to nursing diagnosis study: 1 ; publication of article in nursing diagnosis in reference journals: 2; Article published on nursing diagnoses with relevant content to the area: $2 ; \mathrm{PhD}$ in the field of nursing diagnosis: 2; Clinical experience, at least one year in the study area of diagnosis: 1 and Certificate (specialization) of relevant clinical practice in the field of the diagnostics studies: 2 . The higher the score, the greater the strength of the assessment evidence ${ }^{(7)}$.

The sample consisted of 52 Brazilian nurses who had, at least, a master degree, who worked with nursing diagnoses and patient care in the post-operative period, teaching or researching. Participants with scores lower than five were excluded according to Fehring's(5) ${ }^{(5)}$ criteria, regarding the selection of experts. The selection of participants was done through active search for expert professionals of the above areas, in the Lattes Platform of the National Council for Scientific and Technological Development - CNPq (Lattes and Research Groups Directory) and by snow ball sampling type, which consists in selection of participants, by appointment or recommendation of previous participants ${ }^{(8)}$.

An instrument of data collection, consisting of two parts, was prepared: the first containing identification and professional experience (expert) data, and the second related to the nursing diagnosis validation of nausea (statement, definition, position it occupies in the data structure and defining characteristics with their operational definitions, described on a Likert scale). The expert was asked to assign a value to each defining characteristic of nausea diagnosis on a scale of 1 to 5 , wherein the number 1 represented the category of not relevant and the number 5 highly relevant. A review of the statement, the definition and taxonomic structure was based on three judgments: I agree, I partially agree and I disagree.

After developing the questionnaire, we conducted an appearance and content validation by five PhDs nurses and experts in the thematic nursing diagnosis and perioperative nursing through an adapted instrument ${ }^{(4)}$. High levels of agreement were obtained in relation to the form, scope and appearance of the instrument and small suggestions were proposed to improve the clarity and objectivity of the instrument, which were agreed in its totality. 
Data collection began with a telephone call or a message sent by email to the expert nurse. At that moment, experts were informed about the study and were invited to participate. Upon positive response, the participant expressed interest in responding to the research in a printed or digital form. In the first contact, we asked the nurse's address for posting the Consent Form (CF), questionnaire and stamped envelope for later reply. If the option was digital form, the CF and the questionnaire, previously created in Microsoft Word software, were sent by email. The questionnaire was returned with the answers filled in, and the Consent Form was scanned by the expert and sent to the researcher by email. During this first contact, we asked them for information about other nurses with expert profiles (Figure 1). Data collection period lasted for four months (March-June 2011) and it was performed by the researcher.

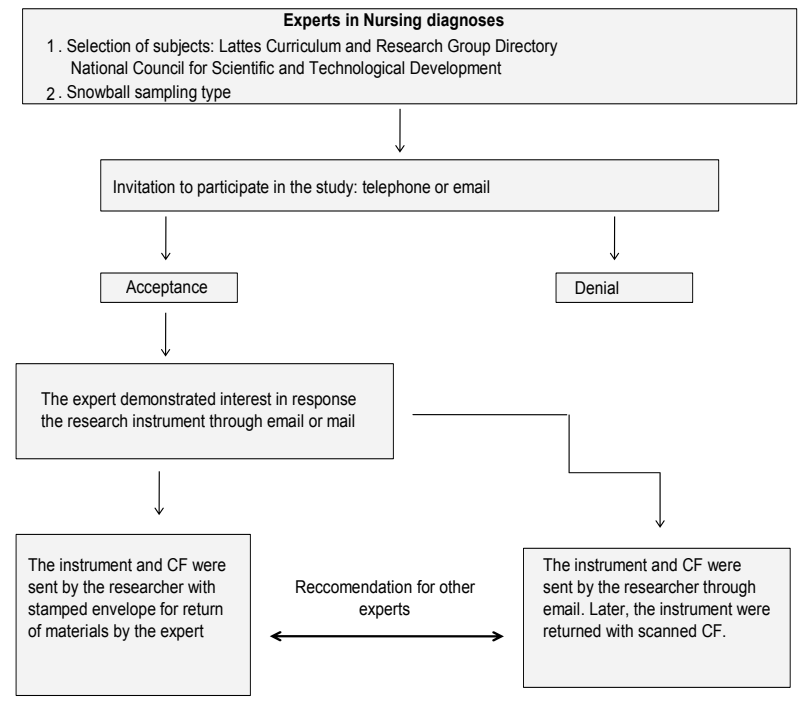

Figure 1 - Flowchart of data collection step of content validation of nursing diagnosis of nausea

The returned questionnaires by the experts were analyzed and each defining characteristic received a score (1 - highly relevant; 0.75 - very pertinent, 0.50 - some relevance; 0.25 - somehow relevant; 0 - not relevant) ${ }^{(5)}$. Then, we calculated the weighted averages and subsequent classification of elements - higher weighted average or equal to 0.80: Primary; averages between 0.50 and 0.79: Secondary and average lower than 0.50: irrelevant. Finally, the total DCV was calculated from the sum of the weighted averages divided by the total number of defining characteristics.

The analysis of the responses of the experts as to the statement, definition and position in the taxonomic structure (I agree, I partially agree and I disagree) was performed using simple frequency.

The research project was approved by the Ethics Committee (EC) of the Faculty of Medicine of Sao Jose do Rio Preto - FAMERP as determined by Resolution 196/96 of the National Board of Health for research involving human subjects (Protocol No. 0456/2011).

\section{RESULTS}

We sent 80 invitations to qualified nurses so that they could participate as experts. From the total invited, 21 did not respond to the invitation, four declined because they did not consider themselves experts on the subject of the research, two were excluded because they did not reach the minimum score to be considered an expert and one did not accept due to lack of time. Thus, the sample consisted of 52 expert nurses, most were female (96.15\%) (Table 1).

Table 1 - Characterization of expert participants from the content validation step of the nursing diagnosis of nausea - Sao Jose do Rio Preto, SP 2011

\begin{tabular}{lccccc}
\hline Data on experts & Mean & Median & SD & Max. value Min. value \\
\hline Age & 44.02 & 45.00 & 10.49 & 68.00 & 26.00 \\
$\begin{array}{l}\text { Time they have } \\
\text { worked as a } \\
\text { nurse }\end{array}$ & 20.92 & 21.00 & 10.50 & 45.00 & 3.00 \\
\hline
\end{tabular}

Most participants had a PhD (75\%), followed by $17.31 \%$ who were $\mathrm{PhD}$ candidates during the research and $7,69 \%$ had a master's degree. Regarding professional occupation, $42.31 \%$ were professors, researches and provided care service, $42.31 \%$ were professors and researches, $3.85 \%$ were researches and provided care services, $5.77 \%$ were professors and provided care services, $3.85 \%$ were only professors and $1.92 \%$ were only researches. The areas of expertise of the professional participants were: nursing diagnosis $(40.38 \%)$, peri-operative nursing and nursing diagnosis $(30.77 \%)$, peri-operative nursing $(25 \%)$ and others (3.84\%).

From the 52 experts who participated in the study, 45 $(86.54 \%)$ claimed to identify nursing diagnoses in their practice always $(19.23 \%)$, often $(48.07 \%)$, rarely $(28.85 \%)$ and never (3.85\%). The experts who answered never are those who do not use nursing diagnosis in their current practice.

Most participants (75\%) achieved a score equal to or greater than 11 in the selection criteria of the experts. The mean score was 11.63 points, the median was 12 points, the standard deviation was 2.24 and the range was 7-14 points.

Most nurses (82.69\%) agreed with the location of diagnosis of nausea in the domain 12 , Comfort. Six nurses (11.54\%) partially agreed, and three $(5.77 \%)$ disagreed. Comments made by nurses who partially agreed or disagreed were: nausea could be allocated for domain 3 Elimination/exchange or for the domain 11 - Safety/Protection; there is no other domain where the diagnosis fits; the definition of the domain must be improved to be appropriate to the diagnosis. 
Forty-one nurses (78.85\%) agreed with the fact that the nursing diagnosis of nausea should remain in Class 1 Physical Comfort; $15.35 \%$ and $5.77 \%$ partially agreed and disagreed, respectively. The reasons given by nurses who disagreed or partially agreed were: definition of the class physical comfort needs to be reviewed; nausea diagnosis should also be contained in Classes 2 (Environmental Comfort) and Class 3 (Social Comfort).

Most experts agreed that the nausea statement is appropriate to the diagnosis (98.08\%). Only one expert partially agreed considering that nausea could be a defining characteristic and not a nursing diagnosis.

Most experts agreed that the definition of nausea is adequate (82.70\%). Eight (15.38\%) partially agreed, and one $(1.92 \%)$ disagreed. The statements of the experts who partially agreed and disagreed were: a) exclude the subjective definition of the word; nausea is a subjective sensation, but also an objective symptom for the possibility of objective verification of suggestive signs of nausea; b) insert in the definition aspects related to the intensity of nausea; $c$ ) insert the background to the concept of nausea; d) replace the terms throat, epigastrium and abdomen by a single term - abdominal region; e) further specify the statement a wave at the back of the throat; f) present a new definition (subjective sensation of disgust to food, including its odor. Rising sensation of vomiting, and accompanied by signs such as: hypersalivation, diaphoresis, tachycardia, pallor and tachypnea).

The experts judged the relevance of the defining characteristics of the nursing diagnosis of nausea. Table 2 shows the maximum, minimum, weighted mean and standard deviation values of each defining characteristic evaluated. The defining characteristics may be considered primary, secondary and irrelevant.

Four defining characteristics were considered primary (reported nausea, increased salivation, aversion to food and vomiting sensation), and eight were called secondary (increased swallowing, sour taste in the mouth, pallor, tachycardia, diaphoresis, sensation of hot and cold, changes in blood pressure and pupil dilation).

The total score of the nursing diagnosis was 0.79 .

Table 2 - Defining characteristics of the nursing diagnosis of nausea, according to the score obtained in the content validation - Sao Jose do Rio Preto, SP 2011

\begin{tabular}{|c|c|c|c|c|}
\hline \multirow{2}{*}{ Defining characteristics } & \multicolumn{2}{|c|}{ Range } & \multirow{2}{*}{$\begin{array}{c}\text { Wheighted } \\
\text { mean }\end{array}$} & \multirow{2}{*}{ SD } \\
\hline & Value máx. & Value mín. & & \\
\hline Reported nausea & 1 & 0.75 & 0.94 & 0.11 \\
\hline Vomiting sensation & 1 & 0.5 & 0.94 & 0.12 \\
\hline Increased salivation & 1 & 0.25 & 0.85 & 0.2 \\
\hline Aversion to food & 1 & 0.25 & 0.8 & 0.23 \\
\hline Pallor & 1 & 0 & 0.79 & 0.25 \\
\hline Increased swallowing & 1 & 0 & 0.78 & 0.22 \\
\hline Diaphoresis & 1 & 0 & 0.77 & 0.27 \\
\hline Tachycardia & 1 & 0 & 0.75 & 0.27 \\
\hline Sour taste in the mouth & 1 & 0.25 & 0.74 & 0.21 \\
\hline Sensation of hot and cold & 1 & 0 & 0.74 & 0.27 \\
\hline Changes in blood pressure & 1 & 0 & 0.71 & 0.27 \\
\hline Pupil dilation & 1 & 0 & 0.67 & 0.32 \\
\hline
\end{tabular}

\section{DISCUSSION}

The content validation is based on the opinion of experts on the topic under study, therefore, the identification and selection of these professionals become the focus in studies using this methodological approach. Inadequate choice of experts selection criteria may interfere with the reliability of the results, since these experts will be responsible for the task of judging how each component studied will represent the diagnostic class, and hence this should be investigated in clinical validation ${ }^{(9)}$.

Obtaining experts have been a difficulty in the validation studies of nursing diagnoses ${ }^{(9-10)}$, since there is disagreement in the literature regarding the necessary requirements for defining an Expert. Additionally to the small number of experts in the thematic of nursing diagnoses and often lack of time of these professionals to respond the research questions with thematic oriented to validation. Authors add that, in order to invite nurses experts from other countries, linguistic and cultural aspects must taken into account ${ }^{(9)}$.

Other studies of content validation showed higher, similar or lower number of experts when compared to the number of experts in this search: 120 nurses (nursing diagnosis of anxiety)(11), 72 experts (nursing diagnosis of spiritual anguish)(12), 60 experts (diagnosis of risk for 
vascular trauma) ${ }^{(13)}, 58$ experts (nursing diagnosis of nausea) $)^{(14)}, 50$ experts (diagnosis of deficient knowledge) $)^{(4)}, 32$ experts (diagnostic of sexual dysfunction and ineffective sexuality pattern) ${ }^{(15)}, 16$ experts (diagnostic of fear and anxiety) ${ }^{(16)}, 21$ experts (nursing interventions for patients with diabetes mellitus) ${ }^{(17)}$.

Most experts were females, a fact associated with the historical context of the profession, in which men are discouraged to follow nursing due to a stereotypical view of homosexuality, low salaries and less respect of the community in comparison to other Professional classes ${ }^{(18)}$.

The average age of the experts who participated in the study was 44.02 years; and the average time they have worked as a nurse was 20.92 years. Other authors of similar studies reported these variables as important positive points for identifying an $\operatorname{Expert}^{(12,16)}$. The work experience of nurses is essential because it can help in the early identification of real or potential health problems presented by the patients, and as professional practice continues, it was observed that the clinical experience increases proportionally with the time of practical experience. Practical experience, skills and values are constituted in different type of knowledge, which has a strong influence on decision making. While the explicit elements are taught formally, tacit elements are acquired during observation and practice ${ }^{(19)}$.

Regarding certification, $75 \%$ of the participants had PhDs, $17.31 \%$ were PhD candidates and $7.69 \%$ had a master's degree. The more certificates, the more researches were conducted and/or the greater the clinical experience of the nurse, the more expert they will be ${ }^{(9)}$.

In this study, experts were professors, researchers and provided care services $(42.31 \%)$ or they were professors and researches (42.31\%). The experience in different fields of work is an important characteristic of the expert to the reliability of the results, in a content validation ${ }^{(4)}$. The identification and use of nursing diagnoses in clinical practice, despite being part of the process of nursing work and being regulated by the Federal Nursing Council Resolutions $272 / 2002$ and $358 / 2009$, although not imposed in many health institutions, as a consolidated activity by professional nurses.

It is assumed that the professionals who work in the three levels of activities (education, research and care services) has the most frequent habit of performing clinical investigations and questioning practice, seeking reasons to support their care and education in scientific knowledge. In addition, nurses who work only in care services, often have difficulties for periodic professional development such as: lack of time, excessive working hours, difficult to use databases, lack of knowledge about research methods and not valuing the professional who do research or consume it in institutions. Therefore, working in education, research and care services is an important factor to be considered when choosing the expert, even though the model used in this study considers that the expert should have only the clinical experience of at least one year in the field of the studied diagnostics.

The working area of most nurses was the nursing diagnosis $(40.38 \%)$, peri-operative nursing and nursing diagnosis $(30.77 \%)$ and peri-operative nursing $(25 \%)$. The symptom of nausea is present not only in the context of the surgical patient, but also in many and varied clinical situations. Moreover, it is a lived experience, often by all people throughout life.

Although the nursing diagnosis of nausea is common in the nursing practice, for a nurse to be considered an expert in a particular area, other aspects besides clinical practice should be considered, such as: certification, performance of researches and knowledge on nursing diagnosis, often, he/she will have to give an opinion regarding not only the presence of defining characteristics, but also on the position of nursing diagnosis taxonomy, concepts and definitions surrounding the phenomenon studied.

There are differences between nurse specialists and expert. The first term refers to the professional who has special skills or knowledge in a particular practice or activity, and the second relates to the nurse who has specialized body of knowledge or skills, extensive experience in the specific field of practice, high level of development for pattern recognition and quality of expert recognized by others ${ }^{(9)}$. A specialist nurse can be considered an expert in a particular subject and therefore participate in validation studies as a judge, as long as he/she is an expert in the field in which the researcher proposes to investigate ${ }^{(9)}$.

Most professionals obtained a score equal to or greater than 11 (75\%). The higher the score, the higher the degree as well as practical and research experience of nurses. All nurses had clinical experience of at least one year in the nursing diagnosis or peri-operative nursing area, and most published articles related to the topic of nursing diagnosis.

Based on experience of clinical experience, it is observed that many nurses may be using nursing diagnoses in order to comply with a requirement and not focusing on this activity as a tool to assist in identifying and solving patients' problems. In a study with the objective to verify why the nursing process is not configured as the nurse main activity in everyday practice, the authors identified problems in the operationalization of the steps of the nursing process: data collection ( $28.7 \%)$, nursing diagnosis $(58.5 \%)$, planning $(32 \%)$ and evolution $(34.2 \%)^{(20)}$.

Nursing diagnosis is the step in which nurses have more difficulty and often the diagnostic category of nausea is ignored when symptoms are not followed by vomiting.

To develop a nursing diagnosis, the nurse needs to be familiar with the taxonomic structure of NANDA-I and to be based on domains and classes to identify diagnoses quickly and with less probability of errors. Thus, the
Content validation of the nursing diagnosis of nausea Pompeo DA, Rossi LA, Paiva L 
experts opined about the ideal location of the diagnostic taxonomy in study. Most agreed that nausea should belong to the domain 12- Comfort. The domain 3 (Elimination/exchange) and domain 11 (Safety/protection) were cited as possible domains. Other experts also suggested modifying the definition of the domain Comfort.

The domain 3, Elimination/exchange, is defined as: secretion and excretion of waste products from the body ${ }^{(21)}$. The word excretion is defined as the disposal of waste by the body and excrete means expelling the body by natural means. Secretion is the production and release of substances from glands ${ }^{(22)}$. This domain has been discarded because nausea may or may not be followed by vomiting. When not followed by vomiting, it generates no elimination of gastric contents into the external environment.

The domain 11, Safety/protection, is defined as: being free from danger, injury, or damage to the immune system; conservation against loss and protection of safety and absence of risks ${ }^{(1)}$. The expert who opined on this domain has not justified his/her response. Maybe his/her choice has been directed to avoid the risk of aspiration during the expulsion of gastric contents or to excessive loss of fluids and electrolytes that occurs due to repetitive episodes of vomiting. In both situations, vomiting, necessarily, should be present, therefore, not being characterized as a suitable domain to the diagnosis of nausea.

These two terms (nausea and vomiting) generate quite confusion, since they are two highly related complications that often occur together; however, both should be evaluated independently ${ }^{(23)}$. Vomiting occasionally occur without the sensation of nausea, stating that only certain parts of the vomiting center are associated with sensation of nausea ${ }^{(24)}$.

There is no possibility of inclusion of the nursing diagnosis of nausea in the domains cited by experts in the fields (Domains 3 and 11) and their corresponding classes, since class is the subdivision of the domain. Most experts $(78.85 \%)$ agreed that nausea should remain allocated to Class 1 - Physical Comfort.

Comfort or discomfort may occur in four contexts of human experience: physical, psycho-spiritual, sociocultural and environmental contexts ${ }^{(25)}$.

Physical comfort includes all bodily sensations and homeostatic mechanisms of the individual. The psychospiritual comfort refers to the internal awareness of the individual, including self-esteem, self-concept, sexuality and meaning of life. The sociocultural comfort is defined by interpersonal, family and social relationships (finance, family traditions, rituals and religious practices). Environmental comfort is defined as external human experiences, such as temperature, sound, odor, color, among others ${ }^{(25)}$.

Nausea and pain may have physiological, psychological, sociocultural and environmental components, however, nausea is evidenced mostly in the physical context ${ }^{(25)}$, corroborating NANDA-I taxonomy and the results of this study.
In a study about the domain 12 - Comfort, from NANDA-I taxonomy, the authors concluded that for this component, it is consistent with the Comfort Theory and with their classes, some modifications would be needed, such as: the development of a fourth class, called psycho-spiritual comfort, and the name of the third class changed from social comfort to sociocultural comfort ${ }^{(25)}$. The nursing diagnosis of Impaired Comfort was inserted into the taxonomy in 2008 and, by its definition, it is observed by encompasses the phenomena described in the theory of comfort (perceived lack of sense of comfort, relief, and transcendence in the physical, psycho-spiritual, environmental and social dimensions) $)^{(1)}$.

It is common to observe in the evolution of nurses, only the label of the documented nursing diagnosis, such as: nausea, acute pain, ineffective breathing pattern, hypothermia, among others. Other times, it appears that the identification of a nursing diagnosis was made without prior consultation with the definition of the diagnosis in question. Therefore, the statement should be thought of as an important element of a diagnosis. We should reflect upon the condition in which the individual is. Almost all nurses considered that the term nausea is suitable for this nursing diagnosis.

One expert considered that nausea would be a defining characteristic and not a diagnosis. As hyperthermia and pain, nausea corresponds to an individual's response to real or potential health problems. Nurses can perform various nursing activities in a dependent or independent way in relation to the prevention, relief and control of nausea.

In validation of the nursing diagnosis of nausea in cancer patients, we identified that the title Nausea is an adequate and clear description of the phenomenon ${ }^{(14)}$. As important as the label of a nursing diagnosis is its definition, because it is through the definition that the nurse makes the decision about a nursing diagnosis. In this study, most experts agreed that the definition is adequate (82.70\%).

An expert suggested the insertion of the definition that nausea is also an objective symptom, as it can be verified by means of suggestive signs such as pallor, body position and diaphoresis. Others have suggested replacing the words throat, epigastrium and abdomen by a single term; specify better about a wave at the back of the throat and inserted data related to the intensity of nausea and its antecedents.

After analysis and reflection on the opinion of experts, we constructed the following definition for nursing diagnosis of nausea: subjective and unpleasant sensation of discomfort in the back of the throat and/or stomach, mild to intense, which can result in vomiting (Definition of NANDA-I, published in 2010: a subjective unpleasant, wave-like sensation in the back of the throat, epigastrium, or abdomen that may lead to the urge or need to vomit $)^{(21)}$. 
Although there is possibility of verification of nausea through objective signs, this can only be validated after confirmation of the patient. The general appearance of the patient, such as faces, body posture, color and appearance of the skin should be valued. When the nurse finds a curved patient with the hand on abdomen and faces of pain, nurses should then ask if there is presence of pain, since the objective signs offered clues about the pain. In the episode of nausea, the same thing happens. The signs of pallor, sweating, unwell faces and head forward position are clues that lead nurses to question the patient about the presence of nausea. In both situations, the response of the patient is essential.

We inserted the words discomfort and sickness for a better adaptation to the class (physical comfort) and for improved specification of subjective sensation. Unpleasant subjective sensation of what? The expression wavelike sensation in the back of the throat, epigastrium, or abdomen refers to urge to vomit, symptom characterized by muscle events of vomiting but without expulsion of vomit. These muscle events, called antiperistalsis characterize the wave. The antiperistaltic wave, which usually starts in the ileum, travels toward the mouth at a rate of two to three inches per second, pushing a large part of the contents of the lower small intestine back into the duodenum and stomach. The distention of the gastrointestinal tract structures, especially the duodenum, is the excitatory factor for the onset of the act of vomiting ${ }^{(24)}$. However, the patient with nausea does not necessarily have urge to vomit or vomit. Thus, a patient with only symptom of nausea may feel discomfort and sickness, without the sensation of wave.

The words epigastrium and abdomen were removed and replaced with stomach and added the intensity levels of nausea. The abdomen is divided into nine regions: right upper quadrant, left upper quadrant, epigastrium, right flank, left flank, mesogastrium, right iliac fossa, left iliac fossa and suprapubic or hypogastric region ${ }^{(26)}$. It is observed that the term throat is an organ, epigastrium is a region of the abdomen and abdomen consists of nine regions. From this analysis, it was considered important to define exactly where the individual shall present this discomfort (throat and stomach).

The NANDA-I taxonomy ${ }^{(1)}$ showed a change in the definition of nursing diagnosis of nausea: a subjective phenomenon of an unpleasant sensation in the back of the throat and stomach that may or may not result in vomiting. We corroborate to the current version presented by NANDA-I in relation to the location of the symptom (throat and stomach), but there is also a suggestion for the insertion of the nausea intensity. A phenomenon means any amendment brought in bodies by the action of physical or chemical agents; and all that is perceived by the senses or by conscience; wonder; rarity; person distinguished by some extraordinary talent ${ }^{(22)}$. Sensation is defined as a body impression produced in an organ by external objects in the senses, transmitted to the brain by nerves, and determining a judgment or concept ${ }^{(22)}$. Thus, it is believed that the term subjective and unpleasant sense of discomfort and unwell is more relevant than a subjective phenomenon from an unpleasant sensation.

The experts highlighted that the definition needs adjustments. The greater clarity in the definition of a nursing diagnosis, the greater the likelihood that nurses will make accurate diagnoses and succeed in nursing interventions.

The defining characteristics of the nursing diagnosis of nausea were assessed by experts regarding how characteristics were compared to nausea. From the 12 characteristics analyzed, four showed an average equal to or greater than 0.80 and eight have presented average of 0.50 to 0.79 . Reported nausea and vomiting sensation were the defining characteristics with the highest average (0.94), followed by increased salivation (0.85) and aversion to food (0.80).

Nausea is a subjective sensation and the patient's report is the best tool for its confirmation. The vomiting sensation, secretion of small amounts of saliva, pallor, diaphoresis, and sensation of hot and cold occur by stimulation of autonomic signals, mediated by the sympathetic nervous system except the excessive salivation, which is regulated by the parasympathetic nervous system. The impulses are transmitted by vagal and sympathetic afferent fibers to the vomiting center ${ }^{(27)}$. Excessive swallowing is a consequence of excessive saliva.

The aversion to food can occur when the patient is stimulated with food in the first hours after surgery. The smell of food stimulates the cerebral cortex and the vomiting center, causing the patient to verbalize repulsion for food or he/she will assume behaviors as turning his/ her face to the other side of food, shaking his/her head in negative sign and making facial expressions of disgust for food.

Tachycardia is a manifestation presented only in the ejection phase of vomiting(27). Thus, it is assumed that nurses still have difficulty distinguishing the manifestations present in nausea and vomiting.

The instability of the cardiovascular system is common after surgery. The hypotension in the immediate post-operative period is caused by conditions ranging from shock to the vasodilatation induced by blocking sympathetic nerves that control vasomotor tone after spinal anesthesia. Hypertension can be caused by anxiety, pain, hypothermia and hypoventilation ${ }^{(28)}$; consequently, changes in blood pressure appear to be unrelated to the presence of nausea.

The defining characteristics identified in a study on validation of the nursing diagnosis of nausea were: stomach sickness, report of nausea, vomiting sensation (primary or higher weighted average to 0.75 ), aversion to food, increased salivation, sour taste in the mouth and increased
Content validation of the nursing diagnosis of nausea Pompeo DA, Rossi LA, Paiva L 
salivation (secondary or greater than 0.50 and less than 0.75 weighted average $)^{(14)}$. No other studies on the nursing diagnosis of nausea were identified.

Finally, the total score of the nursing diagnosis was calculated, which was 0.79 , considered adequate ${ }^{(5)}$.

This study has limitations related to the set of skills presented by the experts participants in this research. It is possible that a group of experts composed of anesthetists' nurses, specialization which does not exist in Brazil, may have other contributions to this diagnosis in peri-operative nursing.

\section{CONCLUSION}

Nursing diagnosis of nausea, according to experts, should belong to the domain 12- Comfort and to Class 1- Physical Comfort . The statement nausea is clear and appropriate. The definition of nausea, although adequate

\section{REFERENCES}

1. NANDA International. Diagnósticos de enfermagem: definições e classificação. Porto Alegre: Artes Médicas; 2012.

2. Carvalho EC, Rossi LA. A validation of INCP: Alpha Version in Brazil. In: Rantz MJ, LeMone P, editores. Classification of nursing diagnoses: proceedings of the fourteenth Conference of the North American Nursing Diagnosis Association; 2002. Glendale: Cinahl Information Systems; 2002. p. 60-66.

3. Martins QCS, Aliti G, Rabelo ER. Decreased cardiac output: clinical validation in patients with descompensated heart failure. Int J Nurs Terminol Classif. 2010;21(4):156-65.

4. Galdeano LE, Rossi LA, Pelegrino FM. Validação de conteúdo do diagnóstico de Enfermagem Conhecimento deficiente. Acta Paul. Enferm. 2008;21(4):549-55.

5. Fehring RJ. Methods to validate nursing diagnoses. Heart Lung. 1987;16(6):625-9.

6. Pompeo DA, Rossi LA, Galvão CM. Integrative literature review: the initial step in the validation process of nursing diagnoses. Acta Paul Enferm. 2009;22(4):434-8.

7. Fehring RJ. The Fehring model. In: Carrol-Jonhnson RM, Paquete $\mathrm{M}$, editores. Classification of nursing diagnoses: proceedings of the Tenth Conference; 1994. Philadelphia: J.B. Limppincott; 1994. p. 55-62.

8. Polit DF, Beck CT, Hungler BP. Fundamentos de pesquisa em enfermagem: métodos, avaliação e utilização. Porto Alegre: Artmed; 2004. for most participants, needed reformulations for $17.30 \%$ of the experts. The proposed definition for nursing diagnosis of nausea, based on the opinion of experts was: subjective and unpleasant sensation of discomfort in the back of the throat and/or stomach, mild to intense, which can result in vomiting.

The defining characteristics considered primary indicators for nursing diagnosis of nausea were: reports of nausea (0.94), sensation of vomiting (0.94), increased salivation (0.85) and aversion to food (0.80). The defining characteristics classified as secondary to the nursing diagnosis of nausea were: pallor (0.79), increased swallowing (0.78), diaphoresis (0.77), tachycardia (0.75), sour taste in the mouth $(0,74)$, sensation of hot and cold $(0.74)$, changes in systemic blood pressure (0.71) and pupil dilation (0.67). There were no characteristics which were considered irrelevant.

The total score of the nursing diagnosis of Nausea was 0.79 , considered valid for the NANDA-I taxonomy.

9. Galdeano LE, Rossi LA. Validação de conteúdo diagnóstico: critérios para seleção de expertos. Ciênc Cuid Saúde. 2006;5(1):60-6.

10. Carvalho EC, Mello AS, Napoleão AA, Bachion MM, Dalri MCB, Canini SRMS. Validação de diagnóstico de enfermagem: reflexão sobre dificuldades enfrentadas por pesquisadores. Rev Eletr Enferm [Internet]. 2008 [citado 2013 jul. 23];10(1):235-40. Disponível em: http://www.fen.ufg.br/ revista/v10/n1/pdf/v10n1a22.pdf

11. Oliveira NMS, Chianca T, Rassool GH. A validation study of the nursing diagnosis anxiety in Brazil. Int J Nurs Terminol Classif. 2008;19(3):102-10.

12. Chaves ECL, Carvalho ECC, Haas VJ. Validation of the nursing diagnosis Spiritual Anguish: analysis by experts. Acta Paul Enferm. 2010;23(2):264-70.

13. Arreguy-Sena C, Carvalho EC. Risco para trauma vascular: proposta do diagnóstico e validação por peritos. Rev Bras Enferm. 2009;62(1):71-8.

14. Tang JHC. Nausea: a nursing diagnosis validation study. Int J Nurs Terminol Classif. 2006;17(1):57.

15. Melo AS, Carvalho EC, Haas VJ. Características definidoras validadas por especialistas e as manifestadas por pacientes: estudo dos diagnósticos disfunção sexual e padrões de sexualidade ineficazes. Rev Latino Am Enferm. 2008;16(6):951-8.

16. Bergamasco EC, Rossi LA, Carvalho EC, Dalri MCB. Diagnósticos de medo e ansiedade: validação de conteúdo para o paciente queimado. Rev Bras Enferm. 2004;57(2):170-7. 
17. Teixeira CRS, Becker TAC, Citro R, Zanetti ML, Landim CA. Validation of nursing interventions in people with diabetes mellitus. Rev Esc Enferm USP [Internet]. 2011 [cited 2011 Aug 15];45(1):173-9. Available from: http://www.scielo.br/ pdf/reeusp/v45n1/en_24.pdf

18. Varaei S, Vaismoradi M, Jasper M, Faghihzadeh S. Iranian nurses self-perception-factors influencing nursing image. J Nurs Manag. 2012;20(4):551-60.

19. Nobre MRC, Bernardo WM, Jatene FB. A prática clínica baseada em evidências. Parte I-Questões clínicas bem construídas. Rev Assoc Med Bras. 2003;49(4):445-9.

20. Takahashi AA, Barros ALBL, Michel JLM, et al. Difficulties and facilities pointed out by nurses of a university hospital when applying the nursing process. Acta Paul Enferm. 2008;21(1):32-8.

21. NANDA International. Diagnósticos de enfermagem: definições e classificação. Porto Alegre: Artes Médicas; 2010.
22. Houaiss A. Mini dicionário Houaiss da língua portuguesa. Rio de Janeiro: Objetiva; 2010.

23. Stadler M, Bardiau F, Seidel L, Albert A, Boogaerts JG. Difference in risk factors for postoperative nausea and vomiting. Anesthesiology.2003;98(1):46-52.

24. Guyton AC, Hall JE. Tratado de fisiologia médica. Rio de Janeiro: Elsevier; 2011.

25. Kolkaba K. Comfort Theory and practice: a vision for holistic health care. New York: Springer; 2003.

26. Bickley LS. Bates: propedêutica médica. Rio de Janeiro: Guanabara Koogan; 2010

27. Cangiani $L M$, Slullitel A, Potério GMB, organizadores. Tratado de anestesiologia SAESP. São Paulo: Atheneu; 2012.

28. Galdeano LE, Rossi LA, Peniche ACG. Assistência de enfermagem na recuperação anestésica. In: Carvalho $R$, Bianchi $E R F$, organizadores. Enfermagem em centro cirúrgico e recuperação. Barueri: Manole; 2007. p. 267-98. 